\title{
Development of a subtidal epifaunal community at the island of Helgoland
}

\author{
K. ANGER \\ Biologische Anstalt Helgoland (Meeresstation); \\ D-2192 Helgoland, Federal Republic of Germany
}

\begin{abstract}
Epifaunal community development on plexiglas panels submerged in Helgoland Harbour (North Sea) was observed over one year. The course of colonization is described, and some data are presented on autecology, reproduction, and growth rate of particular species. About three months after initial settlement, conditions of coexistence in a mixed barnacle-ascidian community began to change increasingly due to heavy competition for space. The colonial species Botryllus scblosseri proved to be potentially dominant. Shortly before it attained monopolization by replacing barnacles (mainly Elminius modestus), a major physical disturbance eliminated the fast growing ascidian. The roles of physical factors, of biological interactions, and of historical events in community development are discussed in context with succession theory and other concepts evolved more recently. It is concluded that succession-like processes can occur in subtidal fouling communities, but there the existence of a globally stable climax is unlikely. Generally the concept of multistable points seems to be better applicable to marine ecosystems than that of succession in the classical sense. There is considerable need for further natural history observations and experiments as an empirical basis for current theory and modelling.
\end{abstract}

\section{INTRODUCTION}

The use of artificial hard bottom substrata has become a frequently used means in the experimental analysis of marine epibenthic communities, as well as in testing various materials as to their susceptibility to fouling. In the last decade attention was focused increasingly on theoretical considerations: Does succession in the classical sense (Odum, 1969; Horn, 1974) occur in marine communities? Which are the key factors influencing rate and direction of development in such a community? Recently, some extensive and particularly useful reviews on these problems have been given in the articles of Menge (1976), Connell \&x Slatyer (1977), Jackson (1977), Osman (1977), and Sutherland \& Karlson (1977).

Experiments on epifaunal community development in the German Bight have been carried out especially by Dr. H. Kühl, who suggested this study (papers partly listed by Kühl, 1974), and more recently by Luther (1976 a, b, 1977) and Klöckner (1976). Their main interest applied to regional differences in settlement of frequent species, comparison of fouling susceptibility of different substrata, and to autecolo- 
gical details. Markham \& Munda (in prep.) observed algal recolonization on cleared intertidal substrata at the island of Helgoland and discussed it in the context of succession theory.

This study is the first approach to a more synecological view of subtidal fouling communities at Helgoland. Observations on the colonization of an artificial substratum were recorded over one year to contribute to basic data on single species and on empirical evidence for theoretical considerations. Since many questions in this context can be recognized rather than solved within a 12-month-investigation period, further experiments of the same kind are now in progress. The present paper, therefore, is to be treated as an intermediate report within a current ecological discussion.

\section{STUDY AREA}

A wooden frame holding 12 plexiglas panels was suspended from a raft in Helgoland Harbour (Binnenhafen) near the harbour entrance. Older investigations and comparative data on animal and phytal growth on hard substrata around Helgoland are specified by Kühl (1974). The annual cycle of water temperature at Helgoland is given by Weigel (1978), that of chlorophyll, phytoplankton carbon, and some principal ions by Weigel \& Hagmeier (1978) (Fig. 1).

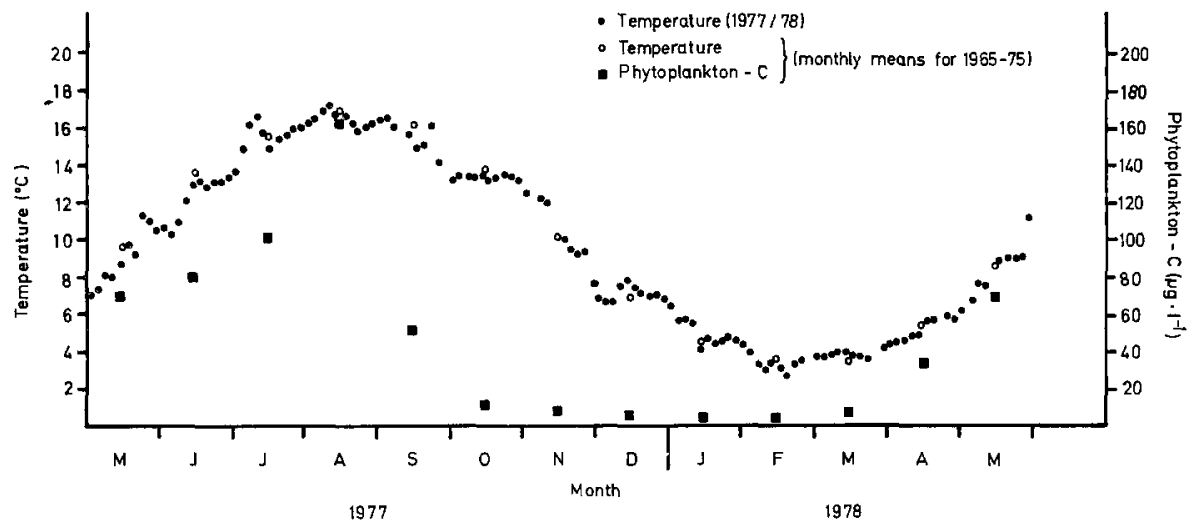

Fig. 1: Annual cycle of temperature and phytoplankton-carbon at Helgoland. Temperature values 1977/78 from Treutner (unpublished), given as arithmetic means of 3-day intervals; monthly means of temperature (1965-1975) from Weigel (1978). Phytoplankton-C values (monthly means) for the same period from Weigel \& Hagmeier (1978)

\section{MATERIALS AND METHODS}

The frame was submerged at the berth of the research vessel "Uthörn" on May 10, 1977, at a depth of $1 \mathrm{~m}$ (upper edge of the frame). Since it was fastened to a floating raft its depth was constant relative to the surface. The area of the transparent panels exposed to colonization was $100 \mathrm{~cm}^{2}$ each and they had a dark 
background. The frame was kept in vertical position by a weight hanging beneath it. The frame hung in such a way that it was always shaded. Kühl (1957) summarized current methods in fouling research; for the present study they were modified as follows: Except for the first and the last month of the experiment, two subsequently positioned panels were exchanged for new ones at about four-week intervals according to the schedule given in Figure 2. In this way, information was gained on colo-

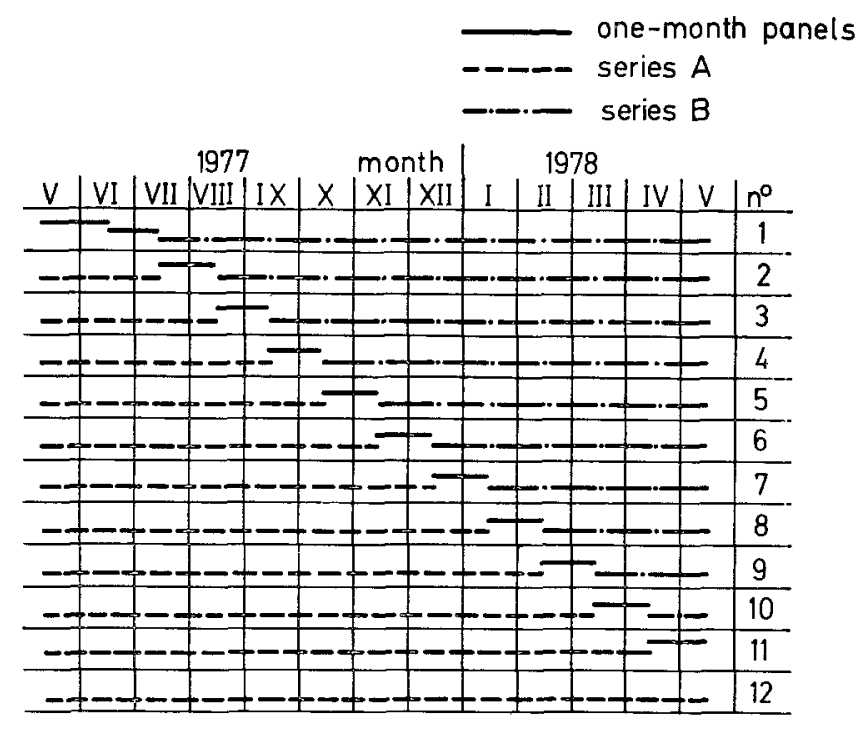

Fig. 2: Time schedule for suspending and sampling of panels

nization both within the preceding month exclusively (one-month panels), and over the total time since the beginning of the experiment (panels of series A, i.e. all panels having been submerged from an identical starting date to different sampling dates). Plexiglas plates which had been exchanged in identical position for the second time (one month as series $A$, four weeks later again as one-month panel) remained suspended for new colonization until the end of the experiment as series B panels, i. e. having different starting dates but identical sampling dates (Fig. 2). After the first month (June, 1977), only the first panel was exchanged; at the end of the study (May, 1978) all panels were taken out.

Unfortunately, plates Nos 2-6 were lost during a heavy storm in February so that series $B$ can be considered only in part. Thus, the comparison of the two series, which would be interesting for the analysis of biological interactions, cannot be made completely.

The epifauna was counted live (except barnacles) under a dissecting microscope. Size measurements were performed by means of a calibrated eye-piece micrometer. After formaldehyde fixation and drying, barnacles were measured, identified, and subsequently marked with a coloured pencil; thus counting errors were excluded. 


\section{RESULTS AND DISCUSSION}

\section{The course of colonization}

A survey of the fouling community observed is given in Table 1. Due no doubt to the very low illuminance of the panels, algal growth was virtually absent and is not considered here. The sequence of colonization by macroscopic animals is shown in Figure 3: From May to June, except for a primary film consisting of

\section{Table 1}

Survey of the fouling community

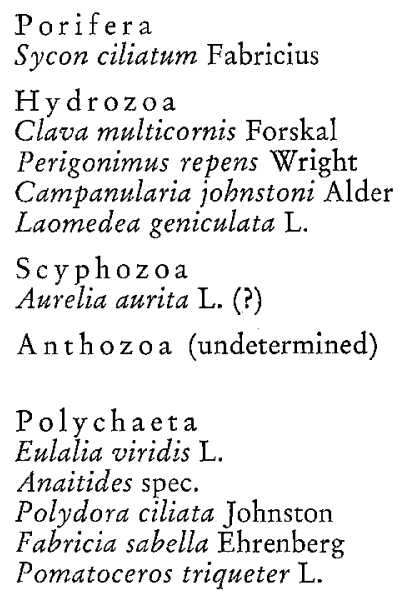

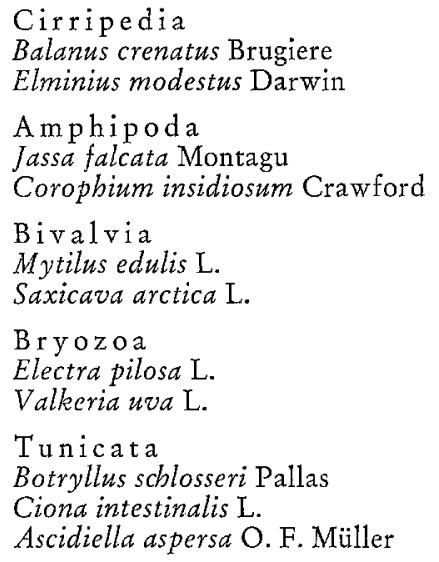

detritus, bacteria, and protozoans (mostly sessile ciliates), only scyphostoma polyps had settled. These scyphozoans could not be identified with certainty; probably they were Aurelia aurita L.

During the following month, the first individuals of Polydora ciliata, Botryllus schlosseri, Valkeria nva, Laomedea geniculata, and a higher number (42 individuals $100 \mathrm{~cm}^{-2}$ ) of Elminius modestus settled on the one-month panel. Some further species occupied only the series-A panel (2 months exposed): Balanus crenatus, Anaitides spec., Fabricia sabella, Saxicava arctica. The three species mentioned last and Polydora ciliata were found only occasionally in the epifauna during the investigation period. This holds true also for a number of further species, which occurred only seldom on panels but are very common in Helgoland waters: Electra pilosa, Pomatoceros triqueter, Jassa falcata, Mytilus edulis, Sycon ciliatum, Clava multicornis, Corophium insidiosum, Eulalia viridis, Ciona intestinalis, and juvenile actinians (undetermined). The time at which these species were found on series-A panels varied without apparent cause, and thus will not be considered in the following description. During the following weeks (July-August) settling of scyphozoans reached its highest level (109 individuals $100 \mathrm{~cm}^{-2}$ month-1) on the one-month panel. 


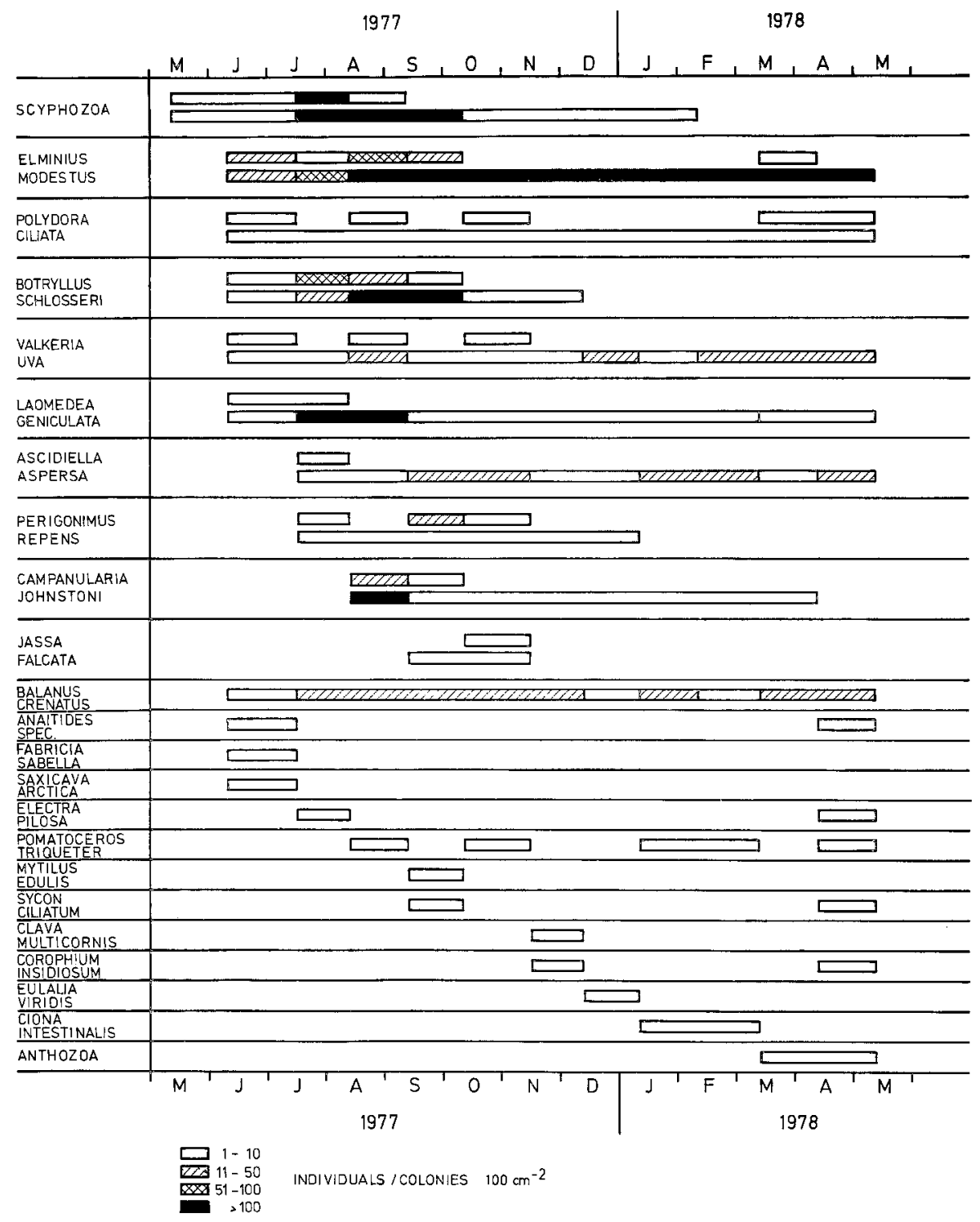

Fig. 3: Course of colonization in the fouling community. Upper bars: 1-month panels; lower and single bars: series-A panels

The frequency of $B$. scblosseri also increased ( 30 colonies comprising 52 ingestion openings), while spatfall of E.modestus declined temporarily to a few individuals $100 \mathrm{~cm}^{-2}$ month ${ }^{-1}$. Ascidiella aspersa and Perigonimus repens occurred for the first time on the panels.

From mid-August to September only a few scyphostoma polyps settled, and they were the last ones of that year. E. modestus, however, attained a new maxi- 
mum (73 individuals $100 \mathrm{~cm}^{-2}$ ) on the one-month panel and B. schlosseri was still frequently settling (36 single "individuals"). On the series- $A$ panel it already covered ca. $15 \%$ of the total area (692 ingestion openings). The stolons of L. geniculata reached their widest expansion at the same time as did the newly invaded hydroid Campanularia jobnstoni. The epifauna became so dense during this period that high quantities of detritus were trapped, together with faeces of ascidians and balanoids, and began to suffocate the expanding hydroid colonies.

Further settlement following the late summer maximum was weak on 1-month panels: only some $B$. schlosseri and E.modestus together with the hydroid P.repens continued to colonize the experimental substratum, the latter species having its maximum settlement in that period (September-October).

On series-A panels, the colonies of $B$. schlosseri expanded more and more over the barnacles, which had been dominant previously in respect to both abundance and percentage cover. More than 3000 ingestion openings were counted on a single panel, the colonies covering about $60 \%$ of the total area. Many balanoids, mostly young individuals, had already been overgrown and had died. A considerable number of newly settled E.modestus, however, succeeded in attaching on the ascidian colonies. The largest individuals of this barnacle species reached sexual maturity at that time. Some large individuals of $A$. aspersa had already grown to a size of $30 \mathrm{~mm}$ and began to cover other species.

This extremely strong competition for space was suddenly changed when in November the chain of the frame broke in a heavy storm, and the frame lay for some days on the muddy sea floor upside down. The colonies of B. schlosseri and most of the scyphozoans were destroyed almost completely, while E. modestus and most other species survived. During the further experimental period (November to May), no more obvious changes occured. Series-B panels which had not been lost (Nos.7-11) showed that during spring 1978, some P. ciliata, E. modestus, and juvenile ascidians (undetermined) had settled, but did not change the community pattern.

\section{Barnacle growth}

The high frequency of barnacles made possible some additional observations in particular on E.modestus, which invaded Helgoland waters as late as in 1954 (den Hartog, 1959).

Settlement, growth and mortality can be recognized in size-frequency distributions (Fig. 4). During the first month of colonization (see 15.07.77) spat can reach almost $3 \mathrm{~mm}$ in diameter at water temperatures of $13-16^{\circ} \mathrm{C}$ and good food availability (cf. Fig. 1). From mid-July to August, when both food supply and temperature are at their highest levels, these barnacles had grown to a size of more than $8 \mathrm{~mm}$ after two months of attached life. During this period, B. crenatus has an even higher growth rate: four weeks after settlement they can reach a size of $6.7 \mathrm{~mm}$, four weeks later up to $13.7 \mathrm{~mm}$.

Later, barnacle growth decreased considerably. In mid-September the largest individuals of E. modestus had a size of $8.6 \mathrm{~mm}$, those of B. crenatus $15.7 \mathrm{~mm}$. In 
October both species nearly reached their maximum size $(9.8$ and $16.6 \mathrm{~mm}$ respectively); some E.modestus were already sexually nature. The largest diameters measured during the investigation period in these two species were 10.4 and $16.8 \mathrm{~mm}$.

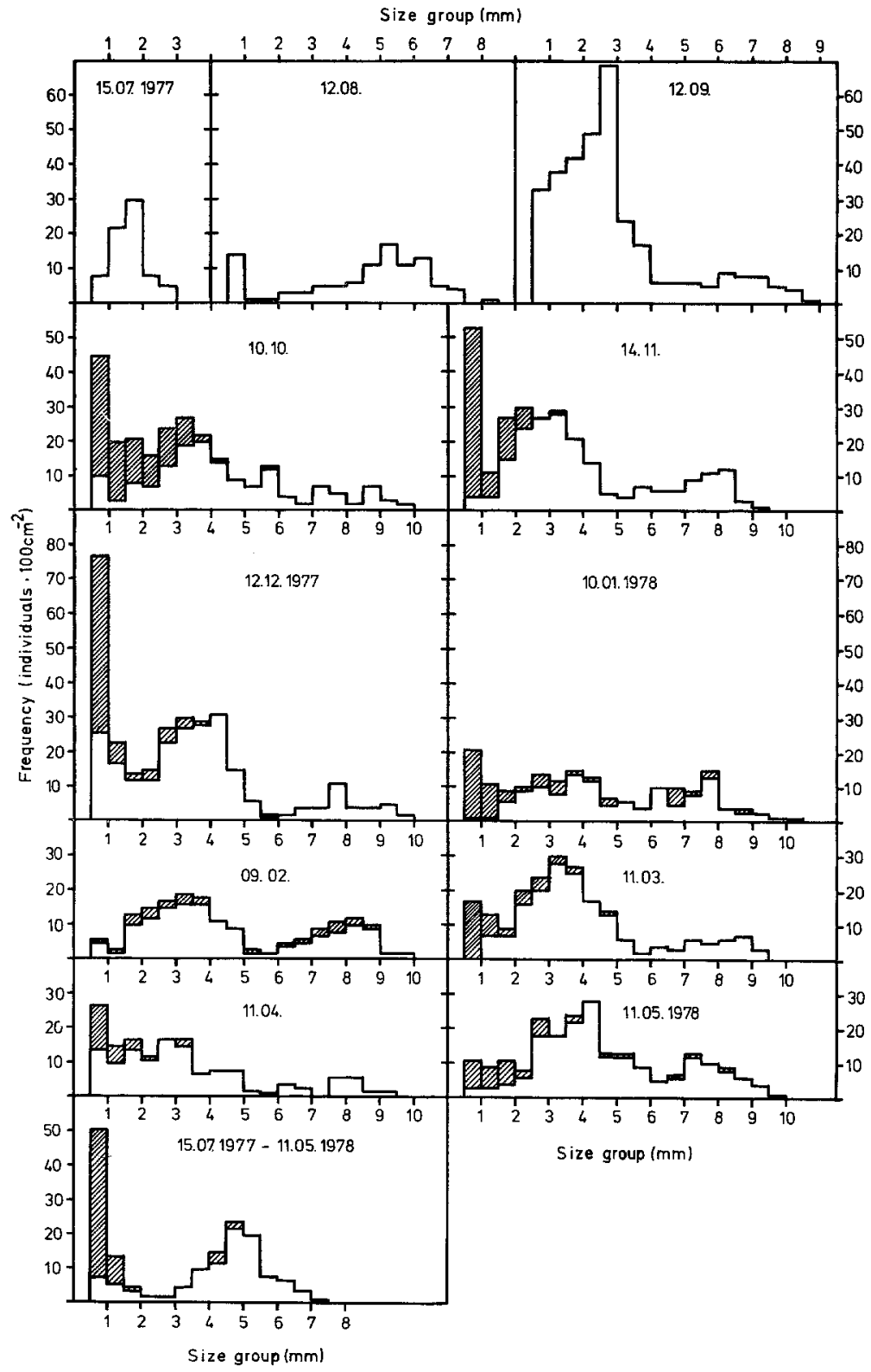

Fig. 4: Elminius modestus: Size-frequency distribution. First graph (15.07.77) from 1-month panel, last graph (15.07.77-11.05.78) from series-B, all others from series-A panels. Shaded areas: dead individuals. Sampling dates are noted on figures (in order: day, month, year) 
The intermediate decrease in settlement intensity of E. modestus (Figs. 3 and 5) in July-August created a bimodal size-frequency distribution. This makes it possible to approximately follow the growth of the second spatfall. During the first month of attached life (see 12.09.) these juveniles also reached about $3 \mathrm{~mm}$ in size, but only 5-6 $\mathrm{mm}$ in the second month. From October, growth ceased, and no more settlement occured.

The recommencement of growth in spring cannot be deduced from series $A$, but is visible in size-frequency distribution in panel No. 1 (series B), because here the first spatfall of 1977 was completely lacking. The largest individuals of the second spatfall reached $7.4 \mathrm{~mm}$ in diameter in May 1978, i.e. less than the first settlers had already reached 9 months before (at an age of only two months). The growth rates estimated during this study in E. modestus and B.crenatus correspond to the observations by Kühl $(1954,1963)$.

The high mortality occurring from October (shaded areas in Figs. 4 and 5) was probably caused almost exclusively by overgrowing colonies of B. schlosseri. Empty shells, but in part also live juveniles, were lost during late autumn and winter because they were attached to ascidians which died later, and due to mechanical stress.

\section{Theoretical aspects and conclusions}

The development of a marine epibenthic community is governed by a highly complex network of biotic and abiotic factors. They have been reviewed in the comprehensive works of Meadows \& Campbell (1972), Connell (1972), Crisp (1974), Scheltema (1974), and in the more recent articles mentioned in the introduction to this report.

Many efforts have been made to examine the influence of physio-chemical factors, which are of particular importance in the rocky intertidal. In this rather harsh environment only relatively few species are able to invade and to interact with each other. Perhaps this is the reason why orderly directional processes can be observed more readily there than in the subtidal zone, which has been investigated in this study. For the latter system, where biological interactions have a relatively higher importance, less is known about whether or not real succession in the classical sense (Odum, 1969) can exist, and if there are any dominant competitors which are successful in the absence of disturbances. Sutherland \& Karlson (1977) deny the existence of such developmental patterns in subtidal fouling communities, but accept them for other systems. They state, however, that the causes for these general differences remain unknown and that therefore more comparative studies of community organization are necessary.

In general, biological interactions (biotic factors) are considered to be much more important in community development than abiotic factors (for wider theoretical discussion see Dayton, 1971; Scheltema, 1974; Connell, 1975; Eagle, 1975; Woodin, 1976; Jackson, 1977; Osman, 1977). This holds partly true even for the intertidal zone (Paine, 1974), though most authors regard this environment as a 
typical physically controlled one. The first interaction taking place in a colonization process is the encountering of a bacterial film by a metamorphosing larva (see above). Somewhat later, adult-larval interactions (intra- and interspecific ones) are often found as attracting forces, but can also result in the destruction of larvae (Mileikovski, 1974; Woodin, 1976) or in replacement of earlier colonizers (e.g. Jackson, 1977).

In the present study, physical factors were considered to be of minor importance, although some effects have become evident: Most of the barnacles were oriented with their carinae at an acute angle to the water surface. This pattern is a well-known combined effect of light and predominant current direction (Crisp \& Barnes, 1954; Crisp \& Stubbings, 1957). The orientation of barnacles, however, is a peculiarity not influencing community patterns.

The accidental destruction of ascidian colonies will be discussed later as a historical event within a succession-like process. As a further abiotic environmental factor affecting colonization, the surface contour has to be taken into consideration. The smooth transparent panels as used for this experiment are a technical convenience for the investigator, but an inconvenience for many settling larvae (for review of surface effects see Crisp, 1974). This might lead to selective exclusion of species as early colonizers and thus might have influenced our results. Figure 3 illustrates the striking fact that only less than half of all species could be observed on one-month panels. A primary film composed of sessile ciliates (Zoothamnium spp., Folliculina spp.) and of many other microorganisms develops fast, according to Daniel (1955), within ca. 48 hours. It occurred during the whole year and was particularly dense in spring and summer. Nevertheless, this initial stimulus for epifaunal colonization (cf. the classical article by Scheer, 1945) is not sufficient for many species, which need a more pronounced structural heterogeneity of the habitat. Among the species found during this study, this fact is known, e.g. for Ciona intestinalis and Mytilus edulis (Scheer, 1945), Polydora ciliata (Hempel, 1961), and Pomatoceros triqueter (Klöckner, 1976). In barnacles a "rugophil" settlement (i.e. preference for concavities) was observed by Crisp \& Barnes (1954). This fact leads to the phenomenon of gregariousness. Figure 5 shows the cumulative settling density (sum of spat on 1 -month panels) in E. modestus as a curve. The numbers on series-A panels, however, are markedly higher (bars). This must be interpreted as evidence for aggregative settlement. Besides a mechanical aspect, it probably also has a chemical one: substances located in the integument of adults are recognized by larvae of their own or closely related species and stimulate them to settle in the immediate neighbourhood of the adults (Crisp \& Meadows, 1962).

The results of this study reveal aggregative settlement as an intraspecific interaction not only for Elminius modestus (c.f. also Knight-Jones \& Stephenson, 1950), but with some likelihood also for syphozoans, Ascidiella aspersa, and Laomedea geniculata. It is also known for Balanus crenatus (Knight-Jones, 1953), Pomatoceros triqueter (Klöckner, 1976) and many other species which are not discussed here because they were not found in this study or did not play any conspicuous role.

Later in colonization the sign of intraspecific interaction may change from attraction toward competition (e.g. Barnes \& Powell, 1950; for review of this 


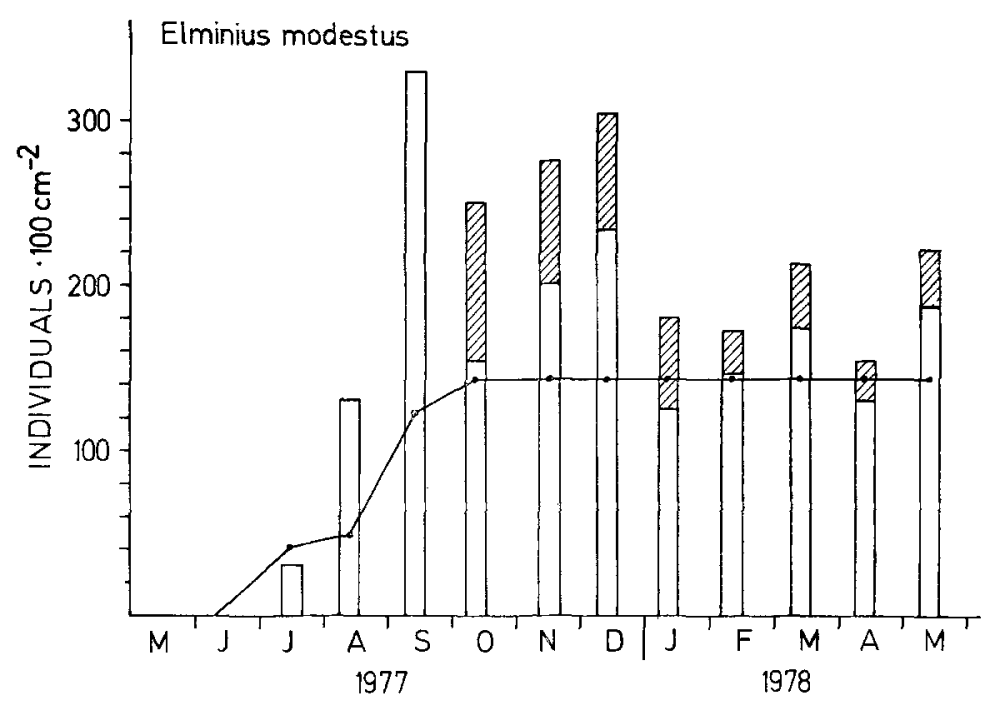

Fig. 5: Elminius modestus: Cumulative settlement numbers. Solid line: addition of subsequent 1 -month panels; bars: series-A panels. Shaded areas: dead individuals

aspect see Knight-Jones \& Moyse, 1961). Intraspecific competition, however, had little importance during the relatively short experimental period, and thus is not considered here.

All these species (including the microorganisms of the primary film observed on the panels) have a common feature: they alter the substrate they occupy, i.e. they "prepare" it for later arrivals. But since most of them do that primarily for their own species, they do not provide much evidence for the "facilitation" model of early succession by Connell \& Slatyer (1977), unless it is proven that e.g. balanoids are an obligate prerequisite for settlement of stronger competitors (e.g. ascidians) by creating a higher spatial heterogeneity. On the contrary the strongest competitor found in this experiment, Botryllus scblosseri, and a similarly superior species, Ascidiella aspersa, were observed to coexist with earlier colonizers, while being easily able to settle in the absence of other macroscopic fouling organisms. This finding is in good agreement with the "tolerance" model (Connell \& Slatyer, 1977), but contradicts the "inhibition" model, which is supported by the observations of Sutherland \& Karlson (1977). The former model also predicts the extinction in time of early settlers by later ones. This process was already going on in the colonization investigated here before a major disturbance interrupted it: Overgrowing of barnacles by Botryllus schlosseri seemed to be a directional process until the successfully competing ascidian colonies were eliminated by physical suffocation while the balanoids and other early invaders survived. The course of these interspecific interactions, i.e. the replacement of solitary forms by colonial ones, agrees well with Jackson's hypothesis of a general superiority of the former over the latter organisms in an undisturbed, space-limited system (Jackson, 1977). Causes of this frequent 
mechanism are found in different growth and reproductive patterns (e.g. limited linear growth versus budding, i.e. exponential, potentially indeterminate growth; seasonal production of pelagic larvae versus almost continuous asexual reproduction). Moreover, colonial forms exhibit more effective competitive mechanisms (c.f. Jackson \& Buss, 1975) and often less susceptibility to predators and to epizoan recruitment. This generalization, although grossly applicable for the present experiment, must not be overestimated, since vertical growth (escape in size) and aggregation favour some frequent solitary invertebrates (e.g. Ascidiella aspersa, Ciona intestinalis, Mytilus edulis).

The developmental mechanisms discussed here also correspond to implications of the more general theory of MacArthur \& Wilson (1967) and Pianka (1970): some colonization patterns could be explained by widely accepted attributes of $\mathrm{r}-$ and $\mathrm{K}$-selection respectively, if considering barnacles (i.e. E. modestus) as "opportunistic" early invaders (r-type), and colonial forms like B. schlosseri (usually lacking effective protection against physical stress but being strong competitors) as late succession dominants (K-type).

Both views accept the existence of an orderly community development. Correspondingly they predict the replacement of balanoids by colonial ascidians and the selective extinction of the latter by physical perturbation. Supported by this accordance of predictions and real observations I conclude, contrary to the opinion of Sutherland \& Karlson (1977), that orderly and directional processes can occur in a subtidal fouling community. They can be interpreted as quasi-successional sequences including competitive dominants, but surely not as a real succession in the classical sense (e.g. Odum, 1969), which should correspond rather to the "facilitation" model of Connell \& Slatyer (1977). As shown above, only little evidence was found for this model in the very early stage of development (c.f. also Connell, 1972). Secondly the study period is too short to judge if something like a stable climax revealing "global stability" (Lewontin, 1969) would ever be reached. The arguments of Sutherland \& Karlson (1977) against such a regular developmental pattern with a well-defined final point seem to be very likely. As visible in the early monopolization by $B$. schlosseri, there is also a high probability that diversity in the community will be descreased by the type of competition observed here instead of being increased as predicted by classical succession theory (c.f. also Markham \& Munda, in prep.). In many cases selective predation on dominant species (reviews on this aspect in Connell, 1975; Menge, 1976) or, if higher trophic levels are absent like here, an "optimal" frequency of disturbance (Rützler, 1965; Osman, 1977) prevents dominance and thus maximizes diversity.

Sutherland (1974) reviewed the importance of historical events such as perturbations for community development. In the particular case of a fouling community, the order of larval recruitment proved to be crucial for monopolization. The existence of multiple stable points thus seems to be an undeniable reality (c.f. Lewontin, 1969; Levins \& Culver, 1971; Sutherland, 1974; Sutherland \& Karlson, 1977; Gray, 1977). This means that global stability is the exception, neighbourhood stability is the rule. In the experiment presented here, a historical event changed the direction of a running development (see above), and on panels of series $B$ the date 
of initial exposure determined community structure found later. This is in full agreement with Sutherland's observations. On the other hand, orderly and directtional processes with some predictibility seemingly occur also in subtidal fouling systems.

Thus it is concluded that succession-like development of natural communities is a frequent reality, but it does not necessarily imply a one-way directionality toward only one possible climax. Historical events often cause switching to other directions (which is also a normal process in the pelagic environment: see e.g. Landry, 1977) or a step back to earlier stages. An improved theory of community organization, which is necessary for the derivation of models predicting natural and man-influenced behaviour of ecosystems, should consider the existence of both in the marine environment, i.e., multiple stable points and succession-like sequences leading to them. It needs further empirical evidence for a deeper understanding of such terms as community development, switching, and stability. In particular, the term "succession" needs a re-definition, otherwise it will be avoided by more and more authors, because it has too many meanings (Kain, 1975). The need for more natural history observations and experiments as a basis for modelling, which was stressed e.g. by Dayton (1973) and Gray (1977), becomes striking in the theoretical discussion of such experiments as presented here. Whether community concepts are mere ecological tautologies (cf. the far-reaching criticisms of Peters, 1976; and Wildish, 1977) or useful tools in the future development of more realistic, more reliable and predictive models of ecosystems, can only be decided by empirical disproof or verification.

Acknowledgements. I am grateful to Dr. H. Kühl, senior scientist in fouling research at the Institut für Küsten- und Binnenfischerei, Außenstelle Cuxhaven, who suggested this study, for his advice and for making available the frame and experimental panels. Thanks are also due to Dr. J. Markham, Helgoland, for reading the manuscript and for fruitful discussion. The figures were drawn by Ms. G. Kuntz.

\section{LITERATURE CITED}

Barnes, H. \& Powell, H. T., 1950. The development, general morphology and subsequent elimination of barnacle populations, Balanus crenatus and B.balanoides, after a heavy initial settlement. J. Anim. Ecol. 19, 175-179.

Connell, J. H., 1972. Community interactions on marine rocky intertidal shores. A. Rev. Ecol. Syst. 3, 169-192.

- 1975. Some mechanisms producing structure in natural communities: a model and evidence from field experiments. In: Ecology and evolution of communities. Ed. by M. L. Cody \& J. M. Diamond. Harvard Univ. Press, Cambridge, Mass., 460-490.

- \& Slatyer, R. O., 1977. Mechanisms of succession in natural communities and their role in community stability and organization. Am. Nat. 111, 1119-1144.

Crisp, D. J., 1974. Factors influencing the settlement of marine invertebrate larvae. In: Chemoreception in marine organisms. Ed. by P. T. Grant \& A. M. Mackie. Acad. Press, London, 177-267.

- \& Barnes, H., 1954. The orientation and distribution of barnacles at setrlement with particular reference to surface contour. J. Anim. Ecol. 23, 143-163. 
- \& Meadows, P. S., 1962. The themical basis of gregariousness in cirripedes. Proc. R. Soc. $13,500-520$.

- \& Stubbings, H. G., 1957. The orientation of barnacles to water currents. J. Anim. Ecol. 26, 179-197.

Daniel, A., 1955. The primary film as a factor in settlement of marine foulers. J. Madras Univ. (B) 15, 189-200.

Dayton, P. K., 1971. Competition, disturbance, and community organization: The provision and subsequent utilization of space in a rocky intertidal community. Ecol. Monogr. 41, 351-389.

- 1973. Two cases of resource partitioning in an intertidal community: making the right prediction for the wrong reason. Am. Nat. 107, 662-670.

Eagle, R. A., 1975. Natural fluctuations in a soft bottom benthic community. J. mar. biol. Ass. U. K. 55, 865-878.

Gray, J. S., 1977. The stability of benthic ecosystems. Helgoländer wiss. Meeresunters. 30, $427-444$.

Hartog, C., den, 1959. Die Seepocke Elminius modestus auf Helgoland. Beaufortia 86, 207-209.

Hempel, C., 1961. Über das Festsetzen der Larven und die Bohrtätigkeit der Jugendstadien von Polydora ciliata (Polychaeta sedentaria). Helgoländer wiss. Meeresunters. 7, 80-92.

Horn, H. S., 1974. The ecology of secondary succession. A. Rev. Ecol. Syst. 5, 25-37.

Jackson, J. B. C., 1977. Competition on marine hard substrata: the adaptive significance of solitary and colonial strategies. Am. Nat. 111, 743-767.

- \& Buss, L., 1975. Allelopathy and spatial competition among coral reef invertebrates. Proc. natn. Acad. Sci. U.S.A. 72, 5160-5163.

Kain, J. M., 1975. Algal recolonization of some cleared subtidal areas. J. Ecol. 63, 739-765.

Klöckner, K., 1976. Zur Ökologie von Pomatoceros triqueter (Serpulidae, Polychaeta). I. Reproduktionsablauf, Substratwahl, Wachstum und Mortalität. Helgoländer wiss. Meeresunters. 28, 352-400.

Knight-Jones, E. W., 1953. Laboratory experiments on gregariousness during settling in Balanus balanoides and other barnacles. J. exp. Biol. 30, 584-598.

- \& Moyse, J., 1961. Intraspecific competition in sedentary marine animals. Symp. Soc. exp. Biol. 15, 72-95.

- \& Stevenson, J. P., 1950. Gregariousness during settlement in the barnacle Elminius modestus Darwin. J. mar. biol. Ass. U. K. 29, 281-297.

Kühl, H., 1954. Über das Auftreten von Elminius modestus Darwin in der Elbmündung. HeIgoländer wiss. Meeresunters. 5, 53-56.

- 1957. Arbeitsmethoden für Untersuchung von Bewuchsschutzmitteln. Veröff. Inst. Küst.u. Binnenfisch. 16, 1-11.

- 1963. Die Verbreitung von Elminius modestus Darwin (Cirripedia thoracica) an der deutschen Küste. Crustaceana 5, 99-111.

- 1974. Schiffsbewuchs und Hafenbewuchs. Deutsche Häfen 3 (Helgoland). Schiff Hafen 26 (9), 1-3.

Landry, M. R., 1977. A review of important concepts in the trophic organization of pelagic ecosystems. Helgoländer wiss. Meeresunters. 30, 8-17.

Lewontin, R. C., 1969. The meaning of stability. Brookhaven Symp. Biol. 22, 13-24.

Luther, G., 1976 a. Bewuchsuntersuchungen auf Natursteinsubstraten im Gezeitenbereich des Nordsylter Wattenmeeres. Helgoländer wiss. Meeresunters. 28, 145-166.

- 1976 b. Bewuchsuntersuchungen auf Natursteinsubstraten im Gezeitenbereich des Nordsylter Wattenmeeres: Algen. Helgoländer wiss. Meeresunters. 28, 318-351.

- 1977. Bewuchsuntersuchungen auf Natursteinsubstraten im Gezeitenbereich des Nordsylter Wattenmeeres: sessile und hemisessile Tiere. Helgoländer wiss. Meeresunters. 29, 375-403.

MacArthur, R. H. \& Wilson, E. O., 1967. The theory of island biogeography. Princeton Univ. Press, Princeton, N. J., 203 pp.

Markham, J. W. \& Munda, I. M. Algal recolonization in the rocky eulittoral at Helgoland, Germany. (In prep.) 
Meadows, P. S. \& Campbell, J. I., 1972. Habitat selection by aquatic invertebrates. Adv. mar. Biol. 10, 271-382.

Menge, B. A., 1976. Organization of the New England rocky intertidal community: role of predation, competition, and environmental heterogeneity. Ecol. Monogr. 46, 355-393.

- \& Sutherland, J. P., 1976. Species diversity gradients: Synthesis of the roles of predation, competition, and temporal heterogeneity. Am. Nat. 110, 351-369.

Mileikovsky, S. A., 1974. On predation of pelagic larvae and early juveniles of marine bottom invertebrates by adult benthic invertebrates and their passing alive through their predators. Mar. Biol. 26, 303-311.

Odum, E. P., 1969. The strategy of ecosystem development. Science, N. Y. 164, 262-270.

Osman, R. W., 1977. The establishment and development of a marine epifaunal community. Ecol. Monogr. 47, 37-63.

Paine, R. T., 1974. Intertidal community structure. Experimental studies on the relationship between a dominant competitor and its principal predator. Oecologia 15, 93-120.

Peters, R. H., 1976. Tautology in evolution and ecology. Am. Nat. 110, 1-12.

Pianka, E. R., 1970. On r- and K-selection. Am. Nat. 104, 592-597.

Rützler, K., 1965. Substratstabilität im marinen Benthos als ökologischer Faktor, dargestellt am Beispiel adriatischer Porifera. Int. Revue ges. Hydrobiol. 50, 281-292.

Scheer, B. T., 1945. The development of marine fouling communities. Biol. Bull. mar. biol. Lab., Woods Hole 89, 103-121.

Scheltema, R. S., 1974. Biological interactions determining larval settlement of marine invertebrates. Thalassia jugosl. 10, 263-296.

Sutherland, J. P., 1974. Multiple stable points in natural communities. Am. Nat. 108, 859-873.

- \& Karlson, R. H., 1977. Development and stability of the fouling community at Beaufort, North Carolina. Ecol. Monogr. 47, 425-446.

Weigel, H.-P., 1978. Temperature and salinity observations from Helgoland Reede in 1976. Annls biol., Copenh. 33, 35.

- \& Hagmeier, E., 1978. Chlorophyll, phytoplankton carbon, and nutrients off Helgoland. Annls biol., Copenh. 33, 72-73.

Wildish, D. J., 1977. Factors controlling marine and estuarine sublittoral macrofauna. Helgoländer wiss. Meeresunters. 30, 445-454.

Woodin, S. A., 1976. Adult-larval interactions in dense infaunal assemblages: Patterns of abundance. J. mar. Res. 34 (1), 25-41. 